\title{
What can rheumatologists learn from translational cancer therapy?
}

\author{
Jonathan P Sherlock ${ }^{1,2,3}$, Andrew D Filer', John D Isaacs ${ }^{4}$ and Christopher D Buckley 1,2*
}

Abstract
It is well established that an intimate connection
exists between inflammation and neoplasia. Indeed,
particular chronic infections and autoimmune
processes giving rise to prolonged site-specific
inflammation are known to increase the probability
of the development of specific cancers. Molecular
characterisation of these processes has revealed
profound similarities in the specific molecules
involved in persistence of inflammation and in both
the primary induction of neoplastic processes and
in specification of the preferred anatomic sites of
metastatic spread. The therapeutic importance of these
findings is underscored by the remarkable success
in the treatment of autoimmune pathology using
medications initially developed for use in oncology and
this arena is one of considerable therapeutic promise
for rheumatologists.

An intimate connection between inflammation and cancer has been proposed for decades based upon both biological similarities and clinical observation. Numerous autoimmune diseases are associated with neoplasia, with an elevated risk of lymphoma in Sjögren's syndrome [1] and rheumatoid arthritis [2], and gastrointestinal inflammation in Crohn's disease and ulcerative colitis is likewise associated with increased risk of intestinal neoplasia [3]. Inflammation induced by infectious organisms may also result in neoplasia, as exemplified by the association of Helicobacter pylori infection and gastric cancer, hepatitis $\mathrm{C}$ virus and hepatic cancer [4] and schistosomiasis and bladder cancer [5]. It has been estimated that $15 \%$ of malignancies may be caused by an underlying infection [6].

\footnotetext{
*Correspondence: c.d.buckley@bham.ac.uk

${ }^{2}$ Centre for Translational Inflammation Research, University of Birmingham,

Edgbaston, Birmingham, B15 2TT, UK

Full list of author information is available at the end of the article
}

One of the most fundamental biological similarities between inflammation and cancer is the presence of similar inflammatory cells in these processes, and on occasions these immune cells have been demonstrated to be essential for tumour progression. Mast cells, for example, are required for tumour growth in a model of pancreatic cancer [7] and macrophages promote invasive, metastatic behaviour in murine mammary cancer [8]. The importance of these cellular similarities is underscored by the observation that inhibition of tyrosine kinase activity with imatinib is an established therapeutic strategy in systemic mastocytosis [9] and chronic myeloid leukaemia [10], but has also been reported to be effective in rheumatoid arthritis [11-13]. Tumours frequently manipulate the host immune response - for example, by secreting chemokines to induce a tolerogenic cellular microenvironment - and may stimulate angiogenesis through elaboration of inflammatory cytokines [14]. As well as cells, inflammatory signalling molecules such as NF-kB are often shared between neoplastic and inflammatory conditions, and these molecules promote both processes. Thus, inactivation of this pathway in intestinal epithelial cells results in a direct reduction of tumour incidence, whereas its inactivation in myeloid cells, which cause inflammation, results in a reduction of proinflammatory cytokines and resultant decrease in tumour size [15]. Similarly, both NF-kB and STAT-3 signalling pathways have been strongly implicated in hepatoma development [16]. Further examples of the shared role of molecules in neoplasia and inflammatory arthritis include the Myc oncoprotein, which has also been shown to induce angiogenesis through the elaboration of IL- $1 \beta$ [17]. As well as this role in tumour vascularisation, this cytokine contributes to inflammation in rheumatoid arthritis, as indicated by the effects of IL- $1 \beta$ neutralisation in this disease [18]. Given the importance of the signalling pathway that operates through the mammalian target of rapamycin (mTOR) in both immune and neoplastic cells, attention is currently focussed on therapeutic approaches centred on this molecule for both autoimmune and neoplastic pathologies $[19,20]$.

Suggestions of a causal role of inflammation in cancer emerge from the observation that the development of 
neoplasia in response to inflammation is strongly associated with the chronicity and intensity of the inflammatory stimulus. Patients with high disease activity in rheumatoid arthritis thus have the highest chance of developing lymphoma [2]. Indeed, pro-inflammatory molecules produced within inflammatory lesions can themselves directly promote genomic instability, as exemplified by reactive oxygen and nitrogen species that result in DNA damage [21]. Early experiments demonstrated that culture with neutrophils elaborating reactive oxygen species endows fibroblasts with an ability to induce tumour development when transferred into mice [22]. Moreover, the rapid cell proliferation associated with inflammation results in further cellular susceptibility to DNA damage in an environment where, in addition, DNA repair processes are themselves compromised. Coculture of activated neutrophils with human alveolar epithelial cells reveals that neutrophils and the hypochlorous acid that they produce can strongly inhibit nucleotide excision repair (NER) of damaged DNA and this effect can be abrogated by inhibiting production of hypochlorous acid [23]. Inflammatory cells, moreover, express tissue degradative enzymes and promote angiogenesis, processes that aid neoplastic cells to metastasise.

That inflammation itself can induce genetic mutation and thus predispose to neoplastic development is demonstrated by the spontaneous inflammatory bowel disease that develops in interleukin-10 deficient mice, since this is associated with a colonic mutation rate five times greater than wild-type mice, with a ten-fold increase in small deletions and insertions to DNA [24]. Indeed, mutations of p53 are found in both human inflammatory bowel disease [25] and rheumatoid synovium [26]. In addition to compromised p53 activity through mutation, this molecule can also be functionally inhibited by the pro-inflammatory molecule macrophage migration inhibitory factor [27], demonstrating another important means by which inflammation, if unchecked, can potentially induce dysregulated cellular proliferation.

The shared use of chemokine receptors in driving both tissue-specific inflammation and tissue-specific metastases of neoplastic cells has received increasing attention. Indeed, the chemokine receptors CXCR4 and CCR7 are expressed on breast cancer tumours and metastases, and their ligands highly expressed in the preferential metastatic sites [28]. Differential expression of chemokine receptors on different tumours and their ligands in metastatic sites explains the differential patterns of metastases, just as these molecules co-ordinate immune cell trafficking.

The extremely potent pro-inflammatory cytokine IL-23 demonstrates a further central connection between autoimmune disease and cancer. This cytokine is central to autoimmune inflammation and has been shown to play a fundamental role in spondyloarthropathy, for which it is a promising therapeutic target [29]. However, IL-23 is also expressed within the vast majority of human carcinomas, where it promotes inflammation and expression of degradative enzymes such as MMP9 [30]. In neoplastic settings, IL-23 inhibits protective antitumour immunity. In addition to IL-23, other proinflammatory cytokines have been demonstrated to be important in promoting neoplasia, with TNF, IL-1 and IL-6 playing key roles in ovarian cancer [31], and these molecules are established therapeutic targets that are neutralised in routine clinical practice for rheumatoid arthritis $[18,32,33]$.

The intimate connection between inflammation and cancer has encouraged the use of anti-inflammatory agents to halt neoplastic development. Indeed, aspirin has been shown to reduce the incidence of cancer [34] and mice with deficiency in the COX enzymes that this drug targets have reduced skin tumorigenesis [35]. Indeed, the reduced incidence of gastrointestinal and gynaecological cancers in rheumatoid arthritis patients has been attributed to non-steroidal anti-inflammatory drug (NSAID) use [36]. Many chemotherapeutic agents are in clinical use not only for treatment of cancer, but also for immune-mediated inflammation, prime examples being cyclophosphamide and methotrexate. Moreover, modern biological agents are also efficacious in both settings. Thus, rituximab is used to treat haematological malignancy, being effective in follicular and mantle cell lymphoma and diffuse large B cell lymphoma [37], but also significantly improves clinical outcomes in rheumatoid arthritis [38]. Even TNF blockade, which some view as potentially facilitating oncogenesis, may also be viewed as protective against cancer development with recent studies conducted in renal cell and ovarian carcinoma [39-42].

Both inflammatory conditions [43] and cancer [44] are associated with extensive modulation of local stromal tissue, with elaboration of pro-inflammatory molecules. Moreover, the aforementioned mutations in p53 in rheumatoid synovium occur in islands of the intimal lining, most likely in type B fibroblast-like synoviocytes, and this is associated with elevated production of IL-6, the latter itself driving inflammation. Indeed, inflammation itself is worse in mice deficient in p53, which develop more severe collagen-induced arthritis [45]. Given the success of agents targeting cancer-associated stromal cells in general and the fibroblast markers FAP [46] and CD248 [47] in particular, targeting similar pathogenic stromal cells in immune-mediated inflammation has already shown [48], and is likely to continue to show, considerable promise.

Abbreviations

IL, interleukin; NF, nuclear factor; TNF tumour necrosis factor. 


\section{Competing interests}

The authors declare that they have no competing interests.

\section{Author details}

'Rheumatology Research Group, University of Birmingham, B15 2TT, UK. ${ }^{2}$ Centre for Translational Inflammation Research, University of Birmingham, Edgbaston, Birmingham, B15 2TT, UK. ${ }^{3}$ Nuffield Department of Orthopaedics, Rheumatology and Musculoskeletal Sciences, University of Oxford, Oxford, OX3 7HE, UK. ${ }^{4}$ Musculoskeletal Research Group, Institute of Cellular Medicine, Newcastle University, NE2 4HH, UK.

\section{Published: 1 May 2013}

\section{References}

1. Kovács L, Szodoray P, Kiss E: Secondary tumours in Sjögren's syndrome. Autoimmun Rev 2010, 9:203-206.

2. Franklin J, Lunt M, Bunn D, Symmons D, Silman A: Incidence of lymphoma in a large primary care derived cohort of cases of inflammatory polyarthritis. Ann Rheum Dis 2006, 65:617-622.

3. Fantini M-C, Pallone F: Cytokines: from gut inflammation to colorectal cancer. Curr Drug Targets 2008, 9:375-380.

4. Chiba T, Marusawa H, Ushijima T: Inflammation-associated cancer development in digestive organs: mechanisms and roles for genetic and epigenetic modulation. Gastroenterology 2012, 143:550-563.

5. Hirao Y, Kim W-J, Fujimoto K: Environmental factors promoting bladder cancer. Curr Opin Urol 2009, 19:494-499.

6. Kuper $\mathrm{H}$, Adami HO, Trichopoulos D: Infections as a major preventable cause of human cancer. J Intern Med 2000, 248:171-183.

7. Soucek L, Lawlor ER, Soto D, Shchors K, Swigart LB, Evan Gl: Mast cells are required for angiogenesis and macroscopic expansion of Myc-induced pancreatic islet tumors. Nat Med 2007, 13:1211-1218.

8. Lin EY, Nguyen AV, Russell RG, Pollard JW: Colony-stimulating factor 1 promotes progression of mammary tumors to malignancy. J Exp Med 2001, 193:727-740.

9. Pardanani A: Systemic mastocytosis in adults: 2012 Update on diagnosis, risk stratification, and management. Am J Hematol 2012, 87:401-411.

10. Jabbour E, Kantarjian H: Chronic myeloid leukemia: 2012 update on diagnosis, monitoring, and management. Am J Hemato/ 2012. 87:1037-1045.

11. Miyachi K, Ihara A, Hankins RW, Murai R, Maehiro S, Miyashita H: Efficacy of imatinib mesylate (STI571) treatment for a patient with rheumatoid arthritis developing chronic myelogenous leukemia. Clin Rheumatol 2003, 22:329-332.

12. Pereira I, Fialho S, Castro G, Zimmermann A: Imatinib mesylate induces clinical remission in rheumatoid arthritis. Joint Bone Spine 2010, 77:372-373.

13. Ames PRJ, Aye WW, Beatty C, O'Reilly D: Imatinib treatment of seropositive arthritis in a young woman with chronic myeloid leukemia. J Rheumatol 2008, 35:1682

14. Marigo I, Dolcetti L, Serafini P, Zanovello P, Bronte V: Tumor-induced tolerance and immune suppression by myeloid derived suppressor cells. Immunol Rev 2008, 222:162-179.

15. Greten FR, Eckmann L, Greten TF, Park JM, Li Z-W, Egan L, Kagnoff MF, Karin M: IKKbeta links inflammation and tumorigenesis in a mouse model of colitis-associated cancer. Cell 2004, 118:285-296.

16. He G, Karin M: NF-KB and STAT3 - key players in liver inflammation and cancer. Cell Res 2011, 21:159-168.

17. Shchors K, Shchors E, Rostker F, Lawlor ER, Brown-Swigart L, Evan Gl: The Myc-dependent angiogenic switch in tumors is mediated by interleukin 1 beta. Genes Dev 2006, 20:2527-2538

18. Mertens M, Singh JA: Anakinra for rheumatoid arthritis: a systematic review. J Rheumatol 2009, 36:1118-1125.

19. Foster JG, Blunt MD, Carter E, Ward SG: Inhibition of PI3K signaling spurs new therapeutic opportunities in inflammatory/autoimmune diseases and hematological malignancies. Pharmacol Rev 2012, 64:1027-1054.

20. LoRusso PM: Mammalian target of rapamycin as a rational therapeutic target for breast cancer treatment. Oncology 2013, 84:43-56.

21. Jena NR: DNA damage by reactive species: Mechanisms, mutation and repair. J Biosci 2012, 37:503-517

22. Weitzman SA, Weitberg AB, Clark EP, Stossel TP: Phagocytes as carcinogens: malignant transformation produced by human neutrophils. Science 1985, 227:1231-1233.
23. Güngör N, Godschalk RWL, Pachen DM, Van Schooten FJ, Knaapen AM: Activated neutrophils inhibit nucleotide excision repair in human pulmonary epithelial cells: role of myeloperoxidase. FASEB J 2007, 21:2359-2367.

24. Sato Y, Takahashi S, Kinouchi Y, Shiraki M, Endo K, Matsumura Y, Kakuta Y, Tosa M, Motida A, Abe H, Imai G, Yokoyama H, Nomura E, Negoro K, Takagi S, Aihara H, Masumura K-I, Nohmi T, Shimosegawa T: IL-10 deficiency leads to somatic mutations in a model of IBD. Carcinogenesis 2006, 27:1068-1073.

25. Brentnall TA, Crispin DA, Rabinovitch PS, Haggitt RC, Rubin CE, Stevens AC, Burmer GC: Mutations in the p53 gene: an early marker of neoplastic progression in ulcerative colitis. Gastroenterology 1994, 107:369-378.

26. Yamanishi Y, Boyle DL, Rosengren S, Green DR, Zvaifler NJ, Firestein GS: Regional analysis of p53 mutations in rheumatoid arthritis synovium. Proc Natl Acad Sci U S A 2002, 99:10025-10030.

27. Hudson JD, Shoaibi MA, Maestro R, Carnero A, Hannon GJ, Beach DH: A proinflammatory cytokine inhibits p53 tumor suppressor activity. J Exp Med 1999, 190:1375-1382

28. Müller A, Homey B, Soto H, Ge N, Catron D, Buchanan ME, McClanahan T, Murphy E, Yuan W, Wagner SN, Barrera JL, Mohar A, Verástegui E, Zlotnik A: Involvement of chemokine receptors in breast cancer metastasis. Nature 2001, 410:50-56

29. Sherlock JP, Joyce-Shaikh B, Turner SP, Chao C-C, Sathe M, Grein J, Gorman DM, Bowman EP, McClanahan TK, Yearley JH, Eberl G, Buckley CD, Kastelein RA, Pierce RH, LaFace DM, Cua DJ: IL-23 induces spondyloarthropathy by acting on ROR- $y t+C D 3+C D 4-C D 8-$ entheseal resident T cells. Nat Med 2012, 18:1069-1076.

30. Langowski JL, Zhang X, Wu L, Mattson JD, Chen T, Smith K, Basham B, McClanahan T, Kastelein RA, Oft M: IL-23 promotes tumour incidence and growth. Nature 2006, 442:461-465.

31. Macciò A, Madeddu C: Inflammation and ovarian cancer. Cytokine 2012, 58:133-147.

32. Feldmann M, Maini RN: Anti-TNF alpha therapy of rheumatoid arthritis: what have we learned? Annu Rev Immunol 2001, 19:163-196.

33. Ash Z, Emery P: The role of tocilizumab in the management of rheumatoid arthritis. Expert Opin Biol Ther 2012, 12:1277-1289.

34. Rothwell PM, Price JF, Fowkes FGR, Zanchetti A, Roncaglioni MC, Tognoni G, Lee R, Belch JFF, Wilson M, Mehta Z, Meade TW: Short-term effects of daily aspirin on cancer incidence, mortality, and non-vascular death: analysis of the time course of risks and benefits in 51 randomised controlled trials. Lancet 2012, 379:1602-1612.

35. Tiano HF, Loftin CD, Akunda J, Lee CA, Spalding J, Sessoms A, Dunson DB, Rogan EG, Morham SG, Smart RC, Langenbach R: Deficiency of either cyclooxygenase (COX)-1 or COX-2 alters epidermal differentiation and reduces mouse skin tumorigenesis. Cancer Res 2002, 62:3395-3401.

36. Mercer LK, Davies R, Galloway JB, Low A, Lunt M, Dixon WG, Watson KD, Symmons DPM, Hyrich KL, British Society for Rheumatology Biologics Register (BSRBR) Control Centre Consortium: Risk of cancer in patients receiving non-biologic disease-modifying therapy for rheumatoid arthritis compared with the UK general population. Rheumatology 2013, 52:91-98.

37. Coiffier B: Rituximab therapy in malignant lymphoma. Oncogene 2007 26:3603-3613.

38. Emery P, Deodhar A, Rigby WF, Isaacs JD, Combe B, Racewicz AJ, Latinis K, Abud-Mendoza C, Szczepanski LJ, Roschmann RA, Chen A, Armstrong GK, Douglass W, Tyrrell H: Efficacy and safety of different doses and retreatment of rituximab: a randomised, placebo-controlled trial in patients who are biological naive with active rheumatoid arthritis and an inadequate response to methotrexate (Study Evaluating Rituximab's Efficacy in MTX iNadequate rEsponders (SERENE)). Ann Rheum Dis 2010, 69:1629-1635.

39. Madhusudan S, Foster M, Muthuramalingam SR, Braybrooke JP, Wilner S, Kaur K, Han C, Hoare S, Balkwill F, Talbot DC, Ganesan TS, Harris AL: A phase II study of etanercept (Enbrel), a tumor necrosis factor alpha inhibitor in patients with metastatic breast cancer. Clin Cancer Res 2004, 10:6528-6534.

40. Madhusudan S, Muthuramalingam SR, Braybrooke JP, Wilner S, Kaur K, Han C, Hoare S, Balkwill F, Ganesan TS: Study of etanercept, a tumor necrosis factor-alpha inhibitor, in recurrent ovarian cancer. J Clin Oncol 2005, 23:5950-5959.

41. Brown ER, Charles KA, Hoare SA, Rye RL, Jodrell DI, Aird RE, Vora R, Prabhakar U, Nakada M, Corringham RE, DeWitte M, Sturgeon C, Propper D, Balkwill FR, Smyth JF: A clinical study assessing the tolerability and biological effects of infliximab, a TNF-alpha inhibitor, in patients with advanced cancer. Ann Oncol 2008, 19:1340-1346. 
42. Harrison ML, Obermueller E, Maisey NR, Hoare S, Edmonds K, Li NF, Chao D, Hall K, Lee C, Timotheadou E, Charles K, Ahern R, King DM, Eisen T,

Corringham R, DeWitte M, Balkwill F, Gore M: Tumor necrosis factor alpha as a new target for renal cell carcinoma: two sequential phase II trials of infliximab at standard and high dose. J Clin Oncol 2007, 25:4542-4549.

43. Flavell SJ, Hou TZ, Lax S, Filer AD, Salmon M, Buckley CD: Fibroblasts as novel therapeutic targets in chronic inflammation. BrJ Pharmacol 2008 153 Suppl 1:S241-246.

44. Mueller MM, Fusenig NE: Friends or foes - bipolar effects of the tumour stroma in cancer. Nat Rev Cancer 2004, 4:839-849.

45. Yamanishi Y, Boyle DL, Pinkoski MJ, Mahboubi A, Lin T, Han Z, Zvaifler NJ, Green DR, Firestein GS: Regulation of joint destruction and inflammation by p53 in collagen-induced arthritis. Am J Pathol 2002, 160:123-130.

46. Kraman M, Bambrough PJ, Arnold JN, Roberts EW, Magiera L, Jones JO, Gopinathan A, Tuveson DA, Fearon DT: Suppression of antitumor immunity by stromal cells expressing fibroblast activation protein-alpha. Science 2010, 330:827-830

47. Maia M, DeVriese A, Janssens T, Moons M, Lories RJ, Tavernier J, Conway EM: CD248 facilitates tumor growth via its cytoplasmic domain. BMC Cancer 2011, 11:162.

48. Maia M, de Vriese A, Janssens T, Moons M, van Landuyt K, Tavernier J, Lories RJ, Conway EM: CD248 and its cytoplasmic domain: a therapeutic target for arthritis. Arthritis Rheum 2010, 62:3595-3606.

doi:10.1186/ar4203

Cite this article as: Sherlock JP, et al.: What can rheumatologists learn from translational cancer therapy? Arthritis Research \& Therapy 2013, 15:114. 